\title{
Infrastructure Development Accelerates Range Expansion of Trembling Aspen (Populus tremuloides, Salicaceae) into the Arctic
}

\author{
Daniel Ackerman ${ }^{1}$ and Amy Breen ${ }^{2}$
}

\author{
(Received 10 September 2015; accepted in revised form 1 December 2015)
}

\begin{abstract}
Interacting forces of climate change and increased human activity in the Arctic are driving rapid changes in ecosystem structure, function, and biodiversity. One such change is the northern range expansion of tree species. We present the first account of the boreal tree species trembling aspen (Populus tremuloides, Salicaceae) growing beyond the latitudinal treeline in the northern foothills of the Brooks Range, Alaska. The four trembling aspen stands described in this paper are located on abandoned gravel roads or pads created for construction purposes. We hypothesize that gravel pads create islands of substrate suitable for tree growth within the Arctic by providing greater rooting depth, well-drained microsites, an extended growing season, and acid-buffering capacity. Further, traffic along the south-to-north oriented Dalton Highway from the boreal forest in Interior Alaska to the Arctic may aid seed dispersal across the topographic barrier of the Brooks Range. Therefore, increased development in the Arctic will likely accelerate the establishment of trees as climate becomes more favorable for tree growth. Tree colonization associated with infrastructure development would contrast sharply with prior conceptual models of gradual treeline advance following disturbance.
\end{abstract}

Key words: trembling aspen; Populus tremuloides; Arctic treeline; range expansion; infrastructure development; human activity; climate change; Brooks Range; Alaska

RÉSUMÉ. Dans l'Arctique, les forces interactives du changement climatique et de l'activité humaine accrue donnent lieu à des changements rapides dans la structure, la fonction et la biodiversité de l'écosystème. Un de ces changements prend la forme de l'expansion des espèces d'arbres dans l'aire de répartition septentrionale. Nous présentons le premier compte rendu au sujet de l'espèce boréale du peuplier faux-tremble (Populus tremuloides, Salicaceae) qui pousse au-delà de la limite forestière latitudinale dans les piémonts du nord de la chaîne de Brooks, en Alaska. Les quatre peuplements de peupliers faux-trembles décrits dans ce texte se trouvent sur des routes ou des remblais de gravier abandonnés créés à des fins de construction. Nous formulons l'hypothèse selon laquelle les remblais de gravier produisent des îlots de substrat qui conviennent à la croissance des arbres dans l'Arctique en raison de la plus grande profondeur d'enracinement, de la présence de microsites bien irrigués, d'une saison de croissance prolongée et de la capacité de tamponnage de l'acide. De plus, la circulation le long de la route Dalton, orientée du sud au nord, depuis la forêt boréale de l'intérieur de l'Alaska jusqu'à l'Arctique pourrait favoriser la dissémination des graines à l'échelle de la barrière topographique de la chaîne de Brooks. Par conséquent, le développement accru de l'Arctique accélérera vraisemblablement l'établissement d'arbres, au fur et à mesure que le climat deviendra plus favorable à la croissance des arbres. La colonisation des arbres liée au développement de l'infrastructure entrerait en contraste marqué avec les modèles conceptuels antérieurs de l'avancement graduel de la limite forestière à la suite de perturbations.

Mots clés : peuplier faux-tremble; Populus tremuloides; limite forestière de l'Arctique; expansion de l'aire de répartition; développement de l'infrastructure; activité humaine; changement climatique; chaîne de Brooks; Alaska

Traduit pour la revue Arctic par Nicole Giguère.

\section{INTRODUCTION}

The latitudinal treeline represents the northern edge of the ecotone between boreal forest and Arctic tundra. Conditions beyond the treeline prevent the growth, survival, and reproduction of trees (Breen et al., 2014): continuous permafrost limits the depth of the active layer where plants can root, and temperature restricts plant growth by suppressing rates of nutrient cycling (Shaver and Chapin, 1980). For these reasons, Arctic tundra vegetation is dominated by short-statured taxa, including shrubs, forbs, graminoids, bryophytes, and lichens.

Arctic plant communities, however, are undergoing rapid change due to the interacting forces of climate change and increased human activity in the region. In the last halfcentury, the Arctic warmed by $2^{\circ} \mathrm{C}$, twice the average

\footnotetext{
${ }^{1}$ Department of Ecology, Evolution, and Behavior, University of Minnesota, 140 Gortner Laboratory, 1479 Gortner Avenue, St. Paul, Minnesota 55108,USA; dackerma@umn.edu

${ }^{2}$ International Arctic Research Center, Scenarios Network for Alaska and Arctic Planning, University of Alaska Fairbanks, PO Box 757245, Fairbanks, Alaska 99775-7245, USA

(C) The Arctic Institute of North America
} 
global rate (Stocker et al., 2013). This warming coincides with increased woody shrub cover (Tape et al., 2006; Myers-Smith et al., 2015). The latitudinal treeline is also predicted to advance northward (Everett and Fitzharris, 1998; Pearson et al., 2013); however, observed rates of treeline advance have been slower than those predicted (Skre et al., 2002; Harsch et al., 2009; Hofgaard et al., 2013). In addition to warming, disturbance may be necessary to facilitate treeline advance by exposing new seedbeds, degrading shallow permafrost, and improving drainage, thereby creating opportunities for establishment in an ecosystem where recruitment is otherwise rare (Landhäusser and Wein, 1993; Lloyd et al., 2002; Chapin et al., 2014).

Infrastructure development associated with oil extraction is a disturbance that alters the physical and chemical characteristics of plant habitat. For example, road construction in the Arctic increases active-layer thaw depth, lengthens the snow-free growing season, and raises $\mathrm{pH}$ in highly acidic soils (Walker and Everett, 1987; Auerbach et al., 1997; Walker et al., 2003; Myers-Smith et al., 2006). On the Arctic Coastal Plain of Alaska, road construction has increased the frequency of thermokarst events, leading to reduced cover of wet sedge tundra and greater cover of woody shrubs (Raynolds et al., 2014). Tracking changes in Arctic plant communities, particularly in woody species with high primary production rates, is vital for modeling vegetation feedbacks to biogeochemical cycles and climate change (Myers-Smith et al., 2011).

In northern Alaska, the treeline at present occurs at $67.9^{\circ} \mathrm{N}$ in the southern Brooks Range (Wilmking et al., 2004). However, small stands of balsam poplar (Populus balsamifera) exist throughout Arctic Alaska, isolated from the species' continuous range to the south by more than $50 \mathrm{~km}$ (Bliss and Cantlon, 1957; Viereck, 1979). Such stands often occur in floodplains of large, spring-fed braided rivers and aufeis deposits, where "thaw bulbs" provide an active layer deeper than that in the surrounding tundra for sufficient rooting depth (Bockheim et al., 2003). Balsam poplar also occasionally occurs on steep south-facing slopes, near warm-water springs, and in sites sheltered from high winds and extreme winter temperatures (Breen, 2014). Point localities of extralimital stands of balsam poplar are reported from Alaska, Yukon (Breen, 2014), and the Northwest Territories (Saarela et al., 2012).

Published accounts of other boreal tree species occurring naturally in Arctic Alaska are limited to white spruce (Picea glauca). Notably, Cooper (1986) reports white spruce from beyond the treeline in the Arrigetch Peaks Region of the Brooks Range and provides a review of past observations of northern spruce populations. However, the only published report of white spruce growing north of the Brooks Range refers to a single sapling growing adjacent to the Dalton Highway, a public road that spans the latitudinal treeline, running from south to north between Alaska's forested Interior and Prudhoe Bay on the Arctic Coastal Plain (Elsner and Jorgenson, 2009).
Trembling aspen has the largest range of any tree species in North America, which underscores its adaptability to a variety of climate and edaphic conditions. In the Northwest Territories, trembling aspen has been shown to invade tundra gradually via seed dispersal following fire (Landhäusser and Wein, 1993). However, there are no previous published reports of trembling aspen in the tundra of the Alaskan Arctic, where the Brooks Range provides a topographic barrier to seed dispersal (Rupp et al., 2001). Here we present the first account of trembling aspen growing beyond the latitudinal treeline in the northern foothills of the Brooks Range in Arctic Alaska (Fig. 1).

\section{OBSERVATIONS OF POPULUS TREMULOIDES IN ARCTIC ALASKA}

\section{Dalton Highway Spur Road}

Two individual trembling aspen saplings, each comprising multiple stems, occur on an abandoned gravel spur road at approximately mile 283.5 of the Dalton Highway (Fig. 2a; $\left.68.6113^{\circ} \mathrm{N}, 149.5491^{\circ} \mathrm{W}\right)$. Each stand has $10-20$ stems that are less than a meter tall. We presume that the multiple stems of these immature stands are clonal. A pressed voucher is deposited in the Herbarium at the Museum of the North, University of Alaska (ALA Accession No: V172804, collected August 2008). The trees are growing in a disturbed gravel substrate that is barren except for a few other early successional willow and graminoid species.

\section{University Toolik Camp}

Several small stands of trembling aspen occur on an abandoned gravel pad that was the site of the decommissioned Alyeska Toolik Camp at the abandoned site of the University Toolik Camp near the current location of the Toolik Field Station in the northern foothills of the Brooks Range (Fig. 2d; 68.6374 $\mathrm{N}, 149.5729^{\circ} \mathrm{W}$ ). A casual survey tallied six stands of multiple individuals $(\sim 1-50)$ that vary in height from 30 to $100 \mathrm{~cm}$, and there was evidence of frequent dieback of the leading stems. These stands are presumed to be composed of several clonal individuals. The trees are immature, as there was no evidence of recent reproduction. Pressed vouchers are preserved in the Toolik Field Station Herbarium, Institute of Arctic Biology, University of Alaska (Accession No: 1568, collected August 2007) and the herbarium of the Museum of the North, University of Alaska (ALA Accession No: V172803, collected August 2008). Several of the stands are growing among dwarf birch (Betula nana) and feltleaf willow (Salix alaxensis spp. alaxensis) trees of similar stature. In addition, our survey tallied at least 10 small stands of balsam poplar at this site. The tallest of these balsam poplar stems is nearly $3 \mathrm{~m}$ tall. 


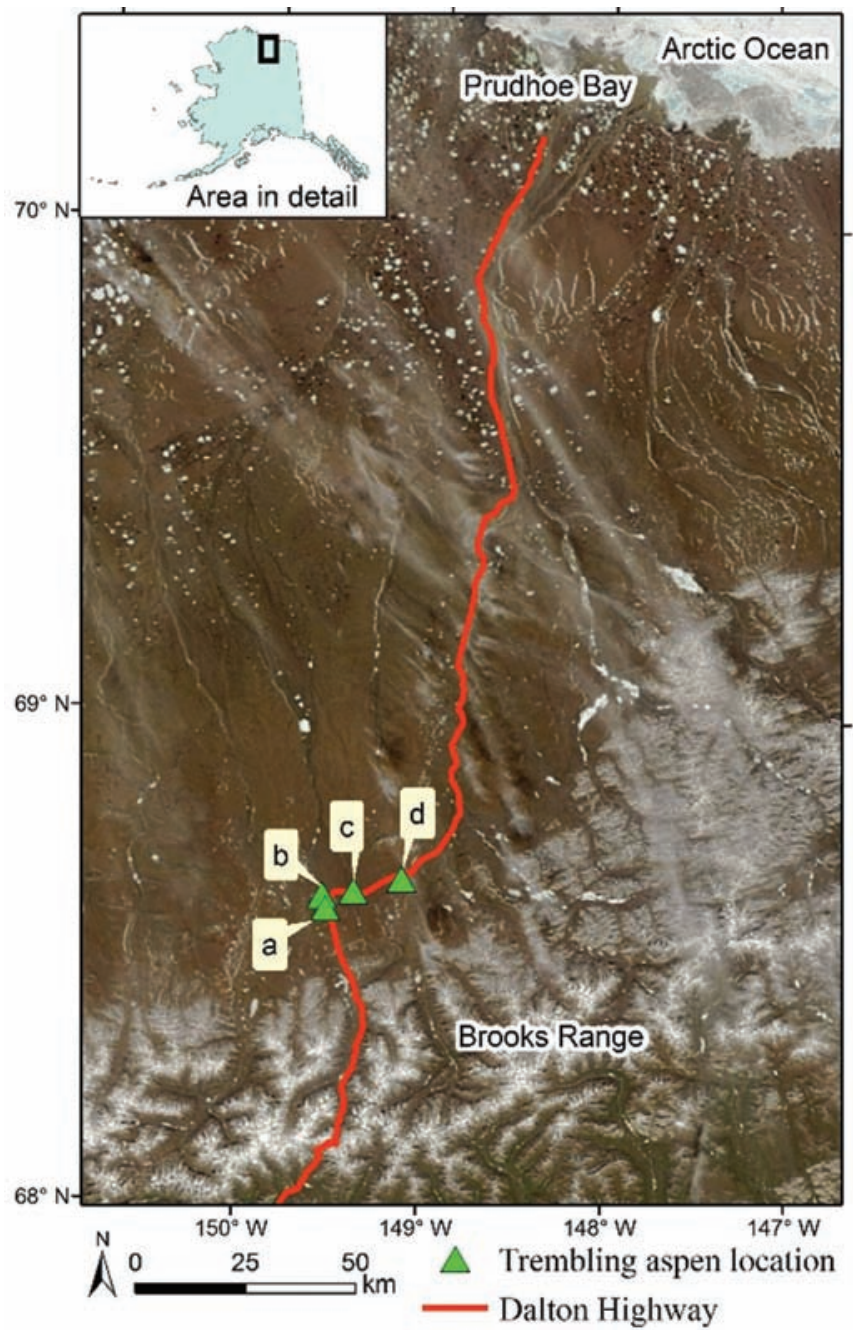

FIG. 1. Locations of four trembling aspen stands (green triangles) at (a) Dalton Highway Spur Road, (b) University Toolik Camp, (c) Kuparuk River, and (d) Oksrukuyik Creek in Arctic Alaska. All occur on abandoned grave pads and roads adjacent to the Dalton Highway (red). The latitudinal treeline corresponds approximately with the southern boundary of the mapped area $\left(67.9^{\circ} \mathrm{N}\right)$. Orthoimagery was acquired by MODIS on 17 June 2013 (NASA, 2013).

\section{Kuparuk River}

A large stand of trembling aspen was discovered in July 2015 growing near the Kuparuk River crossing of the Dalton Highway (Fig. 2b; 68.6473 ${ }^{\circ} \mathrm{N}, 149.3995^{\circ} \mathrm{W}$ ). This stand is also located on an abandoned gravel pad previously used for construction and maintenance of the Trans-Alaska Pipeline. The stand covers approximately $25 \mathrm{~m}^{2}$, with an understory typical of disturbed sites in the region, containing Chamerion angustifolium, Vaccinium vitis-idaea, and a variety of graminoid species. Of the approximately 150 trembling aspen stems, about $90 \%$ are less than $0.75 \mathrm{~m}$ in height, though the tallest stem is $2 \mathrm{~m}$ high. Eight bud scars are evident on this largest stem, indicating it has been growing for at least nine years. As with the other stands described, reproductive structures were absent, and the shorter stems show extensive dieback.

\section{Oksrukuyik Creek}

A smaller stand of trembling aspen was also discovered in July 2015, growing on an abandoned gravel pad at the end of an access road near the Oksrukuyik Creek (Fig. 2c; $\left.68.6746^{\circ} \mathrm{N}, 149.1320^{\circ} \mathrm{W}\right)$. This stand had a single dominant stem that was approximately $1 \mathrm{~m}$ tall, and a count of bud scars indicated it was at least nine years old. Numerous younger stems about $25 \mathrm{~cm}$ tall were growing within a $5 \mathrm{~m}$ radius of the dominant stem. No reproductive structures were evident.

\section{DISCUSSION}

The four trembling aspen stands described here grow on abandoned gravel roads and pads originally installed to support infrastructure development along the Dalton Highway (Fig. 1). Such pads underlie all structures and roads in Arctic Alaska in order to prevent the thermal erosion of permafrost that results when surface vegetation is removed. Since human activity is most common on gravel pads, there may be an element of sample bias to these discoveries of trembling aspen in northern Alaska. However, the tundra surrounding all four trembling aspen sites is being studied intensively by scientists at the Toolik Field Station, which is the Arctic site of the U.S. National Science Foundation's Long Term Ecological Research Network, and construction crews commonly work in the tundra near the Dalton Highway between Toolik Field Station and the Kuparuk River. Therefore, it is unlikely that a stand of trembling aspen would be growing unnoticed in the tundra in these areas.

We argue that gravel roads and pads constitute islands of suitable substrate for trees within the tundra region. Gravel pads are built $2 \mathrm{~m}$ above the ground. Pad margins thus provide a deeper active layer and available oxic rooting depth than the surrounding upland tundra, where thaw depths average just $0.5 \mathrm{~m}$ and standing water is common (Walker et al., 2003). Furthermore, the length of the growing season is extended adjacent to gravel pads by the deposition of low-albedo dust, which absorbs heat and causes early spring snowmelt (Auerbach et al., 1997). This dust, generated by gravel mined from calcareous limestone, also serves as an acid buffer. Moist, acidic tundra, the most common tundra plant community in the northern foothills of the Brooks Range, has a soil $\mathrm{pH}$ that averages 4.0, which is below the ideal range for most tree species (Myers-Smith et al., 2006). Road dust deposition on moist acidic tundra can raise soil $\mathrm{pH}$ from 4.0 to 6.0 , which may be more favorable for trembling aspen and other tree species (Myers-Smith et al., 2006).

The only published account of white spruce on the North Slope (other than those planted experimentally; see Hobbie and Chapin, 1998; Chapin et al., 2014) refers to a seedling on a gravel pad margin (Elsner and Jorgenson, 2009). Several of the known Arctic stands of balsam poplar also grow on abandoned gravel roads and pads (Breen, 2014). 


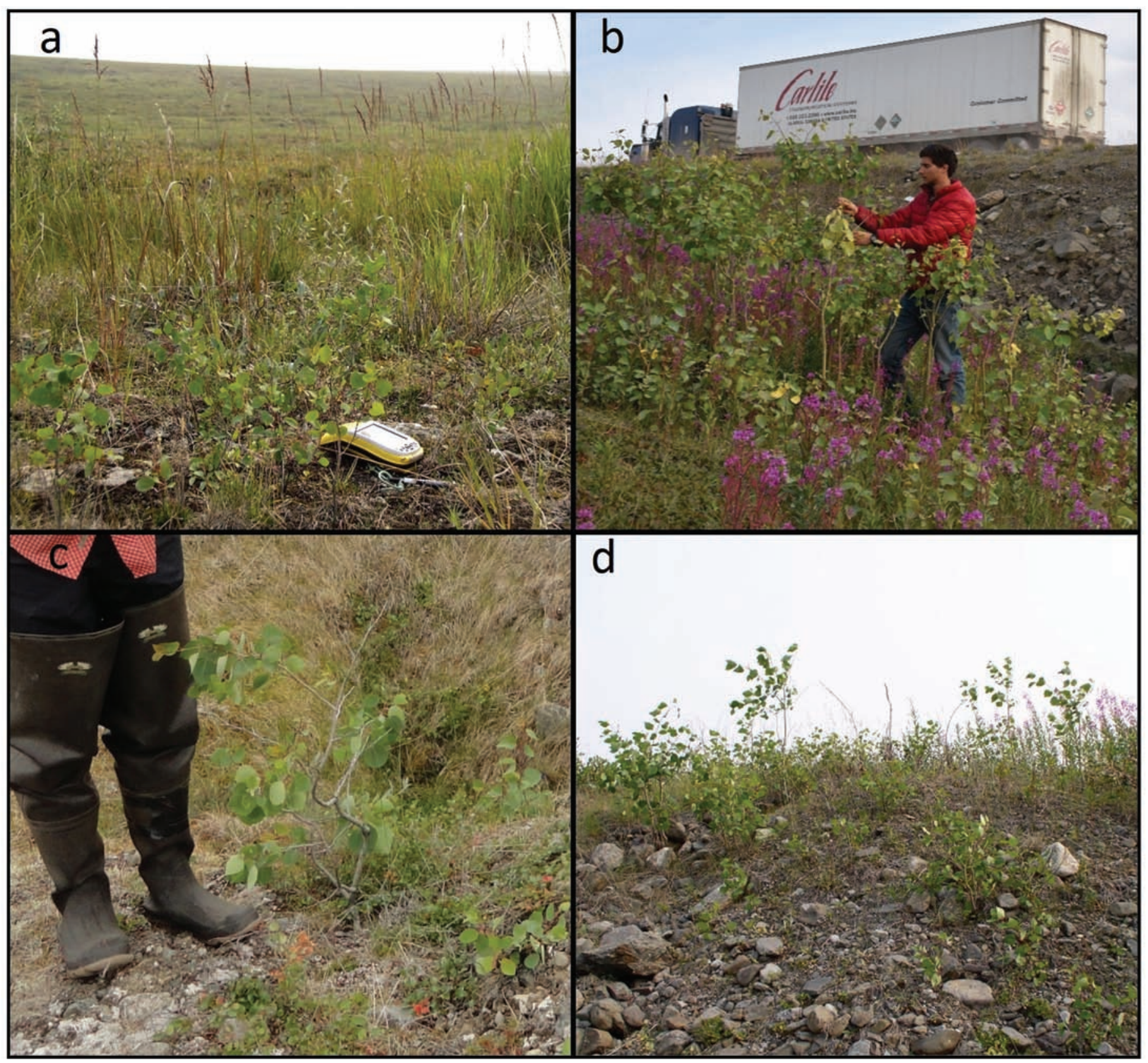

FIG. 2. Photographs of trembling aspen at four sites in the northern foothills of the Brooks Range: (a) Dalton Highway Spur Road, (b) Kuparuk River, (c) Oksrukuyik Creek, and (d) University Toolik Camp.

However, we caution that gravel pads may not be uniformly favorable for tree germination and growth, as some areas of gravel pads have low water retention and nutrient availability (Bishop and Chapin, 1989).

As human activity in the Arctic increases along with gravel extraction and road construction, so too does the probability of tree colonization. Infrastructure development provides both favorable substrate and a viable mode of dispersal. For example, trembling aspen produces small, lightweight seeds that may unintentionally be transported north from the boreal forest within tire grooves or footwear (Ware et al., 2012). Climate change models have suggested that the Brooks Range would block tree advance into the
Arctic for 3000-4000 years after climate becomes favorable for tree growth there (Rupp et al., 2001). Human-aided dispersal, however, would circumvent this topographic barrier. Furthermore, human disturbance facilitates germination and establishment of trembling aspen seeds in the boreal zone, and it could have similar effects in the Arctic (Landhäusser et al., 2010). Also, we cannot rule out that legacy gravel pads were constructed with fill originating from the boreal forest south of the Brooks Range and could have been contaminated with tree seed. This scenario is less probable, however, as trembling aspen seed viability is limited to $2-4$ weeks after maturity (Zasada and Densmore, 1977). 


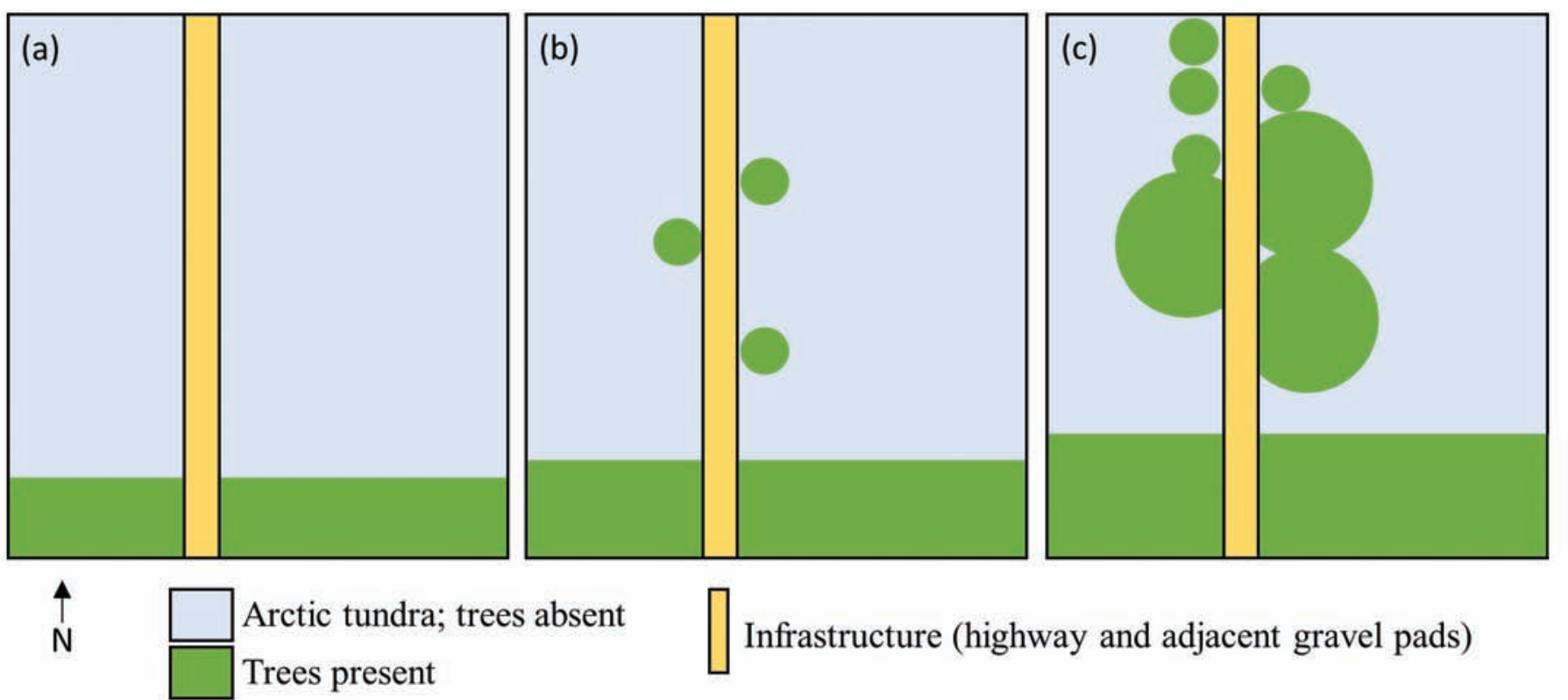

FIG. 3. Conceptual model of tree colonization in the Arctic in three time steps. (a) Present day: The latitudinal treeline occurs at approximately $67.9^{\circ} \mathrm{N}$ in Alaska. (b) Contemporaneous with a gradual treeline advance, patches of trees may establish farther north in association with infrastructure development. (c) Tree patches associated with infrastructure become more numerous, and older patches begin to expand into the natural substrate of the tundra, likely facilitated by disturbance, as climate and edaphic conditions become favorable for tree growth.

If human activity along the Dalton Highway proves to be an important mode of dispersal, then tree colonization of the Arctic may take the form of trees' establishing (as in the four locations described here), growing to sexual maturity, and spreading through seed from gravel pads, rather than a gradual advance of the latitudinal treeline (Fig. 3). This new model of tree establishment associated with infrastructure development contrasts with the findings of Landhäusser and Wein (1993), who demonstrate gradual advance of the treeline following fire in the Northwest Territories. Similarly, Lloyd et al. (2002) report gradual white spruce treeline advance on Alaska's Seward Peninsula following thermokarst events, which degraded permafrost, exposed new mineral soil seedbeds, and improved drainage. Landhäusser and Wein (1993) conclude that the most effective tundra colonizers following disturbance are deciduous trees with wind-dispersed seeds, like the trembling aspen. It is unknown whether these conclusions apply to the northern Alaskan Arctic, where the Brooks Range provides a topographic barrier to natural dispersal.

We observed trembling aspen that likely were dispersed across the Brooks Range by vehicles on the Dalton Highway, though various other species may also experience human-assisted dispersal into the Arctic. Hobbie and Chapin (1998) tested germination and survivorship of seed and seedlings of five tree species in experimentally warmed plots in Arctic Alaska. However, further quantitative study, with emphasis on modes and rates of seed dispersal, is needed to predict the relative likeliness of species-specific colonization. Candidate species include those now known to exist north of the treeline in Arctic Alaska, such as balsam poplar, trembling aspen, and white spruce, as well as those that may become established by the end of the century, such as Alaska paper birch (Betula neoalaskana), black spruce (Picea mariana), or American larch (Larix laricina). Although the latter species are not yet documented north of the treeline in Arctic Alaska, black spruce occurs at the latitudinal treeline in eastern North America, species of larch (Larix gmelinii and Larix sibirica) occur at and beyond the latitudinal treeline in Asia, and a species of birch (Betula pubescens) occurs at the treeline in Scandinavia (CAFF, 2001).

\section{CONCLUSION}

We present the first published account of trembling aspen growing beyond the latitudinal treeline in the northern foothills of the Brooks Range in Arctic Alaska. The four trembling aspen populations described in this paper are found on abandoned gravel roads and pads. We hypothesize that gravel pads constitute islands of suitable substrate for tree growth within the Arctic landscape, which otherwise limits the growth, survival, and reproduction of trees. Gravel pads provide greater rooting depth, an extended growing season, and acid buffering capacity. In addition, highway traffic across the topographic barrier of the Brooks Range may assist seed dispersal. Therefore, human activity and infrastructure development will likely accelerate the predicted colonization of trees in the Arctic as climate becomes more favorable for tree growth. The trembling aspen populations documented here are among the first examples of this trend. These stands will provide an opportunity for biogeographers and population geneticists to study populations in the early stages of range expansion. These trembling aspen also may enable ecosystem ecologists to study biogeochemical 
cycling associated with a novel plant species in the Arctic. We recommend that future efforts to monitor tree colonization in the Arctic focus on areas of high human activity and infrastructure development, such as gravel roads, pads, airstrips, and remote communities. Since tree colonization on a large scale will alter permafrost dynamics and carbon cycling in the Arctic, with ramifications for the global climate system, such monitoring efforts are vital.

\section{ACKNOWLEDGEMENTS}

We thank Joshua P.C. Beneš for reporting the trembling aspen at Oksrukuyik Creek, Sarah Nalven and Tom Glass for photography, the Arctic Long Term Ecological Research site at Toolik Field Station for financial and scientific support, Dr. Teresa Hollingsworth for her insightful feedback about the manuscript, and three anonymous reviewers for their constructive commentary.

\section{REFERENCES}

Auerbach, N.A., Walker, M.D., and Walker, D.A. 1997. Effects of roadside disturbance on substrate and vegetation properties in Arctic tundra. Ecological Applications 7(1):218-235. http://dx.doi.org/10.1890/1051-0761(1997)007[0218:EORDOS] 2.0.CO;2

Bishop, S.C., and Chapin, F.S., III. 1989. Patterns of natural revegetation on abandoned gravel pads in Arctic Alaska. Journal of Applied Ecology 26(3):1073-1081.

http://dx.doi.org/10.2307/2403713

Bliss, L.C., and Cantlon, J.E. 1957. Succession on river alluvium in northern Alaska. American Midland Naturalist 58(2):452 - 469. http://dx.doi.org/10.2307/2422628

Bockheim, J.G., O’Brien, J.D., Munroe, J.S., and Hinkel, K.M. 2003. Factors affecting the distribution of Populus balsamifera on the North Slope of Alaska, U.S.A. Arctic, Antarctic and Alpine Research 35(3):331-340.

http://dx.doi.org/10.1657/1523-0430(2003)035[0331:FATDOP] 2.0.CO;2

Breen, A.L. 2014. Balsam poplar (Populus balsamifera L.) communities on the Arctic Slope of Alaska. Phytocoenologia 44(1-2):1-24. http://dx.doi.org/10.1127/0340-269X/2014/0044-0522

Breen, A.L., Murray, D.F., Raynolds, M.K., Timling, I., and Walker, D.A. 2014. Ecology and evolution of plants in Arctic and alpine environments. In: Rajakaruna, N., Boyd, R.S., and Harris, T.B., eds. Plant ecology and evolution in harsh environments. Hauppauge, New York: Nova Science Publishers, Inc. 149-177.

CAFF (Conservation of Arctic Flora and Fauna). 2001. Arctic flora and fauna: Status and conservation. Akureyri, Iceland: CAFF Working Group.
Chapin, F.S., III, Hollingsworth, T.N., and Hewitt, R.E. 2014. Fire effects on seedling establishment success across treeline: Implications for future tree migration and flammability in a changing climate. Joint Fire Science Program (JFSP) Research Project Reports, Paper 82. Boise, Idaho: JFSP.

Cooper, D.J. 1986. White spruce above and beyond treeline in the Arrigetch Peaks Region, Brooks Range, Alaska. Arctic 39(3):247-252.

http://dx.doi.org/10.14430/arctic2081

Elsner, W.K., and Jorgenson, J.C. 2009. White spruce seedling (Picea glauca) discovered north of the Brooks Range along Alaska's Dalton Highway. Arctic 62(3):342-344.

http://dx.doi.org/10.14430/arctic155

Everett, J.T., and Fitzharris, B.B., eds. 1997. The Arctic and the Antarctic. In: Watson, R.T., Zinyowera, M.C., Moss, R.H., and Dokken, D.J., eds. The regional impacts of climate change: An assessment of vulnerability. A special report of IPCC Working Group II for the Intergovernmental Panel on Climate Change. Cambridge: Cambridge University Press. 85-103.

Harsch, M.A., Hulme, P.E., McGlone, M.S., and Duncan, R.P. 2009. Are treelines advancing? A global meta-analysis of treeline response to climate warming. Ecology Letters 12(10):1040-1049.

http://dx.doi.org/10.1111/j.1461-0248.2009.01355.x

Hobbie, S.E., and Chapin, F.S., III. 1998. An experimental test of limits to tree establishment in Arctic tundra. Journal of Ecology 86(3):449-461. http://dx.doi.org/10.1046/j.1365-2745.1998.00278.x

Hofgaard, A., Tømmervik, H., Rees, G., and Hanssen, F. 2013. Latitudinal forest advance in northernmost Norway since the early 20th century. Journal of Biogeography 40(5):938 -949. http://dx.doi.org/10.1111/jbi.12053

Landhäusser, S.M., and Wein, R.W. 1993. Postfire vegetation recovery and tree establishment at the Arctic treeline: Climatechange-vegetation-response hypotheses. Journal of Ecology 81(4):665-672. http://dx.doi.org/10.2307/2261664

Landhäusser, S.M., Deshaies, D., and Lieffers, V.J. 2010. Disturbance facilitates rapid range expansion of aspen into higher elevations of the Rocky Mountains under a warming climate. Journal of Biogeography 37(1):68-76. http://dx.doi.org/10.1111/j.1365-2699.2009.02182.x

Lloyd, A.H., Rupp, T.S., Fastie, C.L., and Starfield, A.M. 2002. Patterns and dynamics of treeline advance on the Seward Peninsula, Alaska. Journal of Geophysical Research: Atmospheres 107(D2). http://dx.doi.org/10.1029/2001JD000852

Myers-Smith, I.H., Arnesen, B.K., Thompson, R.M., and Chapin, F.S., III. 2006. Cumulative impacts on Alaskan Arctic tundra of a quarter century of road dust. Ecoscience 13(4):503 - 510. http://dx.doi.org/10.2980/1195-6860(2006)13[503:CIOAAT]2. $0 . \mathrm{CO} ; 2$

Myers-Smith, I.H., Forbes, B.C., Wilmking, M., Hallinger, M., Lantz, T., Blok, D., Tape, K.D., et al. 2011. Shrub expansion in tundra ecosystems: Dynamics, impacts and research priorities. Environmental Research Letters 6(4): 045509. http://dx.doi.org/10.1088/1748-9326/6/4/045509 
Myers-Smith, I.H., Elmendorf, S.C., Beck, P.S.A., Wilmking, M., Hallinger, M., Blok, D., Tape, K.D., et al. 2015. Climate sensitivity of shrub growth across the tundra biome. Nature Climate Change 5(9):887-891.

http://dx.doi.org/10.1038/nclimate2697

NASA (National Aeronautics and Space Administration). 2013. Rare clear view of Alaska. NASA image courtesy of Jeff Schmaltz, LANCE MODIS Rapid Response Team. http://earthobservatory.nasa.gov/IOTD/view.php?id=81416

Pearson, R.G., Phillips, S.J., Loranty, M.M., Beck, P.S.A., Damoulas, T., Knight, S.J., and Goetz, S.J. 2013. Shifts in Arctic vegetation and associated feedbacks under climate change. Nature Climate Change 3(7):673-677. http://dx.doi.org/10.1038/nclimate1858

Raynolds, M.K., Walker, D.A., Ambrosius, K.J., Brown, J., Everett, K.R., Kanevskiy, M., Kofinas, G.P., et al. 2014. Cumulative geoecological effects of 62 years of infrastructure and climate change in ice-rich permafrost landscapes, Prudhoe Bay Oilfield, Alaska. Global Change Biology 20(4):1211 - 1224. http://dx.doi.org/10.1111/gcb.12500

Rupp, T.S., Chapin, F.S., III, and Starfield, A.M. 2001. Modeling the influence of topographic barriers on treeline advance at the forest-tundra ecotone in northwestern Alaska. Climatic Change 48(2):399-416. http://dx.doi.org/10.1023/A:1010738502596

Saarela, J.M., Gillespie, L.J., Consaul, L.L., and Bull, R.D. 2012. Balsam poplar (Populus balsamifera; Salicaceae) beyond the tree line in the Western Canadian Mainland Arctic (Northwest Territories). Arctic 65(1):1-12. http://dx.doi.org/10.14430/arctic4161

Shaver, G.R., and Chapin, F.S., III. 1980. Response to fertilization by various plant growth forms in an Alaskan tundra: Nutrient accumulation and growth. Ecology 61(3):662-675.

http://dx.doi.org/10.2307/1937432
Skre, O., Baxter, R., Crawford, R.M.M., Callaghan, T.V., and Fedorkov, A. 2002. How will the tundra-taiga interface respond to climate change? Ambio Special Report 12:37-46.

Stocker, T.F., Qin, D., Plattner, G.-K., Tignor, M.B., Allen, S.K., Boschung, J., Nauels, A., Xia, Y., Bex, V., and Midgley, P.M. 2013. Climate change 2013: The physical science basis. Working Group I Contribution to the Fifth Assessment Report of the Intergovernmental Panel on Climate Change. Cambridge: IPCC.

Tape, K., Sturm, M., and Racine, C. 2006. The evidence for shrub expansion in northern Alaska and the Pan-Arctic. Global Change Biology 12(4):686-702. http://dx.doi.org/10.1111/j.1365-2486.2006.01128.x

Viereck, L.A. 1979. Characteristics of treeline plant communities in Alaska. Holarctic Ecology 2(4):228-238. http://dx.doi.org/10.1111/j.1600-0587.1979.tb01294.x

Walker, D.A., and Everett, K.R. 1987. Road dust and its environmental impact on Alaskan taiga and tundra. Arctic and Alpine Research 19(4):479-489. http://dx.doi.org/10.2307/1551414

Walker, D.A., Jia, G.J., Epstein, H.E., Raynolds, M.K., Chapin, F.S., III, Copass, C., Hinzman, L.D., et al. 2003. Vegetationsoil-thaw-depth relationships along a low-Arctic bioclimate gradient, Alaska: Synthesis of information from the ATLAS studies. Permafrost and Periglacial Processes 14(2):103-123. http://dx.doi.org/10.1002/ppp.452

Ware, C., Bergstrom, D.M., Müller, E., and Alsos, I.G. 2012. Humans introduce viable seeds to the Arctic on footwear. Biological Invasions 14(3):567-577.

Wilmking, M., Juday, G.P., Barber, V.A., and Zald, H.S.J. 2004. Recent climate warming forces contrasting growth responses of white spruce at treeline in Alaska through temperature thresholds. Global Change Biology 10(10):1724-1736. http://dx.doi.org/10.1111/j.1365-2486.2004.00826.x

Zasada, J.C., and Densmore, R.A. 1977. Changes in seed viability during storage for selected Alaskan Salicaceae. Seed Science and Technology 5(3):509-518. 